\title{
Analysis of land use change using normalized difference vegetation index (NDVI) as input parameter to flood risk assessment of Krueng Kluet watershed in South Aceh, Indonesia
}

\author{
Fitri Zaitun Nurnalisa ${ }^{1 *}$, Ella Meilianda ${ }^{1}$, and Azmeri ${ }^{1}$ \\ ${ }^{1}$ Civil Engineering Department, Engineering Faculty, Syiah Kuala University, Banda Aceh, Indonesia
}

\begin{abstract}
Flood events have been escalating in the last decade at the Kluet River, one of the major rivers in the South Aceh district, Aceh Province, Indonesia. The frequent flood events have made remarkable changes to the river morphology including river meander and delta particularly at the downstream. One of the interplaying parameters contribute to flood events is the land use changes in the watershed. This study aimed to analyze the land use changes of Krueng Kluet Watershed using the Normalized Difference Vegetation Index (NDVI). The satellite image data series were obtained to remotely monitor the land use change over 20 years period (1998-2018). NDVI was used in classifying the vegetation density distribution value of the Krueng Kluet Watershed. The output of the study explained that there were increase in the plantation, bareland, grassland, water and settlement areas, while in contrary the forest area and bush. There was an increase by $8.05 \%, 0.15 \%, 0.14 \%, 0.10 \%$, and $0.07 \%$ respectively to the plantation, bareland, grassland, water, settlements/urban areas, during the period of 1998-2018. On the other hand, the forest and bush were significantly decreased by $8.25 \%$, and 0.3 , respectively in the same period. Overall, the land use changes have also increased the Curve Number $(\mathrm{CN})$ of Krueng Kluet Watershed from 61.8 in 1998 to 62.1 in 2008 and to 62.5 in 2018 . This suggests the land use change as an important parameter to take into account in flood risk assessment of the Krueng Kluet Watershed
\end{abstract}

\section{Introduction}

Activities carried out in watersheds influence the ecosystem changes, i.e land use change. The land use change in upstream affects downstream due to water discharge fluctuation, sediment content and other dissolved material content [1].

Flood events have been escalating in the last decade in the Kluet River, one of the major rivers in the South Aceh district of Aceh Province, Indonesia. The report of Aceh Watering Institution, SID (Design Investigation Survey) of The Flood Control and Krueng Kluet River Management in South Aceh District, informed that Krueng Kluet River has several problems including river bank damage. It was effected by the floods transporting the sediments and impacting river capacity reduction [2]. Haba Rakyat also mentioned that River bank erosion due to flood in North Kluet Sub District become higher [3]. The frequent flood events have made remarkable changes of the river morphology, in the form of changing course of river meander and formation of delta by sedimentation, particularly at the downstream. The Krueng Kluet Watershed have been subjected to human-induced land use change for a long time, including intensive deforestation for economic purposes. Any adverse changes occur in the watershed may have been correlated to the changes of the river morphology, and will be potential to increase the risk of flood event in future.

Watershed characteristics highly impacting to surface runoff were watershed area and shape, topography, and landuse. For the dense vegetation landuse, the rain stands in the vegetation before percolating to the soil. The condition affects the low surface runoff. While for bareland area or no vegetation, the rain highly percolate to the soil and affect the high surface runoff flowing to the river. The condition improve the high river flow [4]. The conversion from permeable area to impermeable area influences imbalance ecosystem in a watershed and affects the watershed condition. The land use change impacts surface run off time and volume, and land erosion. In bareland area where no vegetation, the rainfall becomes surface runoff and flows into the river. The improvement of surface runoff volume affects flood and damage of the downstream river area [5].

To comprehend the natural processes or human activities affecting the changes of river morphology, it is required to study the river area condition. This study used Geographic Information System (GIS) and remote sensing. The application of both geographic information systems remote sensing become effective and efficient scientific tool and technique in analyzing the changes of river morphology spatially and temporally. Since the

*Corresponding author: ella meilianda@unsyiah.ac.id 
basic problem identified and the process comprehended, the proper handling can be provided to keep the stable river flow and not endanger the surrounding river area [6].

\section{Method}

\subsection{Data collection}

The data used in this study were secondary data acquired from satellite images. The data can be summarized as follows.

\subsubsection{Land use data}

The land use data used was the Land Satellite Data (LANDSAT) acquired from the United States Geological Survey (USGS) website (http://earthexplorer.usgs.gov/) from 1998 to 2018. There are only three set of satellite data of acceptable quality (e.g., no cloud cover) covering the area of this study, i.e. from the satellite images of 1998, 2008 and 2018.

\subsubsection{Digital elevation model (DEM) data}

Digital Elevation Model (DEM) data is required in this study to obtain topographic data and used in determining watershed border. DEM data can be download from national DEM (DEMNAS) website (http://tides.big.go.id/DEMNAS/).

\subsubsection{Precipitation data}

The rainfall data collected from 1998 to 2018 to calculate surface flow rate was retrieved from the satellite-based rainfall data, which can be downloaded from here http://giovanni.gsfc.nasa.gov/giovanni/. The data was downloaded for the period of 20 years. The maximum rainfall data is $141.49 \mathrm{~mm}$.

\subsection{Analysis technique}

The data analysis phases in this study were divided into three phases, which is summarized as follows:

1. Spatial analysis of topographic data watershed boundary determination;

2. Spatial analysis of land use change;

3. Calculation of the peak discharge using hydrograph of SCS synthetic unit.

\subsubsection{The determination of watershed using DEM}

The analysis of watershed border determination used a hydrology tool in ArcGIS 10.3 software, called "watershed". The placement of the "pour point" is an important step in the watershed delineation process. "pour point" must be located in high flow accumulation area because it is being used to calculate the total water flow contributing to a certain point location..

After all processes finished, it can be continued to the process of river flow area delineation using the
"Watershed" tool resulting "Flow Direction" and "Pour Point" as the inputs. To continue "Geoprocessing" process, watershed raster data is converted into polygon by using "Conversion" tool to process to the next spatial analysis phase [7].

\subsubsection{The analysis of land use change}

Satellite image analysis was started by downloading the land satellite image of 1998, 2008 and 2018. The image cropping was executed based on study area boundary, image improvement, and radiometric correction. Landsat image can be further analysed to classify the land use [8], [9] and [10]. Normalized Difference Vegetation Index (NDVI) in equation (1) can be used to obtain the vegetation density distribution value of the studied watershed.

$$
N D V I=\frac{N I R-R E D}{N I R+R E D}
$$

It explains that NDVI is normalized difference water index, NIR is near infrared, and RED is red reflectance

\subsubsection{Peak discharge analysis using SCS method}

There are several methods to calculate a peak discharge. One of the methods is SCS (Soil Conservation Service) by The Soil Conservation Service (1972), which method computes abstractions from storm rainfall. The hypothesis of the SCS method is that the ratios of the two actuals to the two potential quantities of discharge are equal, that is

$\frac{F a}{S}=\frac{Q}{P-I a}$

From the continuity principle

$P=Q+I a+F a$

$Q=\frac{(P-I a)^{2}}{P-I a+S}$

$I a=0,2 S$

On this basis

$Q=\frac{(P-0,2 . S)^{2}}{P+0,8 . S}$

It describes that $Q$ is excess rainfall $(\mathrm{mm}), \mathrm{P}$ is maximum rainfall $(\mathrm{mm})$, and $\mathrm{S}$ is potential maximum infiltration rate $(\mathrm{mm})$;

The variation between rainfall and surface flow (S) correlate with curve number $(\mathrm{CN})$. The equation can be detailed as below:

$S=\left(\frac{25400}{C N}-254\right)$

Curve number $(\mathrm{CN})$ is varied from 0 to 100 affected by hydrologic soil group of Antecedent Moisture Content 
(AMC). AMC is divided into 3 categories, i.e AMC I (dry), AMC II (normal) and AMC III (saturated) [11]. Based on soil type, AMC, and land use, Watershed CN can be calculated by using the following equation:

$$
C N D A S=\frac{\left(\sum_{i=1}^{n} A i C N i\right)}{\left(\sum_{i=1}^{n} A i\right.}
$$

It explains that $\mathrm{CN}$ is curve number and $\mathrm{Ai}$ is Waterdhed Area (ha)

AMC II (normal) was categorized by infiltration rate and soil texture. This category was divided into 4 (four) groups. They are Group A (sandy soil deep containing dust and clay elements) with infiltration rate of 8-12 $\mathrm{mm} /$ hour, Group B (sandy soil shallower than A, fine to medium texture) with infiltration rate $4-8 \mathrm{~mm} /$ hour, Group C (shallow soil containing sufficient clay) with infiltration rate 1-4 mm/hour, and Group D (mostly clay, shallow, with an impermeable layer near the soil surface) with infiltration rate $0-1 \mathrm{~mm} /$ hour [12].

The SCS dimensionless Hydrograph is a synthetic unit hydrograph in which the discharge is expressed by the ratio of discharge $q$ to to peak discharge $q_{p}$ and the time by ratio of time $t$ to the time of rise of the unit hydrograph, $T_{p}$. Given the peak discharge and lag time for the duration of excess rainfall, the unit hydrograph can be estimated from the synthetic dimensionless hydrograph for the given basin. Figure 1.a shown such a dimensionless hydrograph, prepared from the unit hydrographs of a variety of watershed. The value of $q_{p}$ and $T_{p}$ may be estimated using a simplified model of a triangular unit hydrograph as shown in Figure 1.b, where the time is in hours and the discharge in $\mathrm{m}^{3} / \mathrm{s}$ [13]. From a review of a large number of unit hydrograps, the Soil Conservation Service suggest the time of recession may be approximated as $1.67 T_{p}$. As the area under the unit hydrograph should be equal to a direct runoff of 1 $\mathrm{cm}$, it can be shown:

$$
\begin{aligned}
q_{p} & =\frac{C A}{T_{p}} \\
T_{p} & =\frac{t_{r}}{2}+t_{p} \\
t_{p} & =0,6 \times T_{c}
\end{aligned}
$$

where $\mathrm{C}=$ constant $(2.08), \mathrm{A}$ is the watershed area in square kilometers, and $T_{p}=0.6 T_{c}$. Where $T_{c}$ is the time of consentration of the watershed. The concentration time can be calculated by the Kirpich formula (11)

$$
T_{c}=0,01947 L^{0,77} S^{-0,385}
$$

Were $\mathrm{L}=$ flow length and $\mathrm{S}=$ slope. The coordinate unit hydrograph are given in the Table 1.

Table 1. Coordinate unit hydrograph

\begin{tabular}{|c|c|c|c|c|c|}
\hline $\mathrm{t} / \mathrm{tp}$ & $\mathrm{q} / \mathrm{qp}$ & $\mathrm{t} / \mathrm{tp}$ & $\mathrm{q} / \mathrm{qp}$ & $\mathrm{t} / \mathrm{tp}$ & $\mathrm{q} / \mathrm{qp}$ \\
\hline 0 & 0 & 1 & 1 & 2.4 & 0.18 \\
\hline
\end{tabular}

\begin{tabular}{|c|c|c|c|c|c|}
\hline 0.1 & 0.015 & 1.1 & 0.98 & 2.6 & 0.13 \\
\hline 0.2 & 0.075 & 1.2 & 0.92 & 2.8 & 0.098 \\
\hline 0.3 & 0.16 & 1.3 & 0.84 & 3 & 0.075 \\
\hline 0.4 & 0.28 & 1.4 & 0.75 & 3.5 & 0.036 \\
\hline 0.5 & 0.43 & 1.5 & 0.66 & 4 & 0.018 \\
\hline 0.6 & 0.6 & 1.6 & 0.56 & 4.5 & 0.009 \\
\hline 0.7 & 0.77 & 1.8 & 0.42 & 5 & 0.004 \\
\hline 0.8 & 0.89 & 2 & 0.32 & & \\
\hline 0.9 & 0.97 & 2.2 & 0.24 & & \\
\hline
\end{tabular}

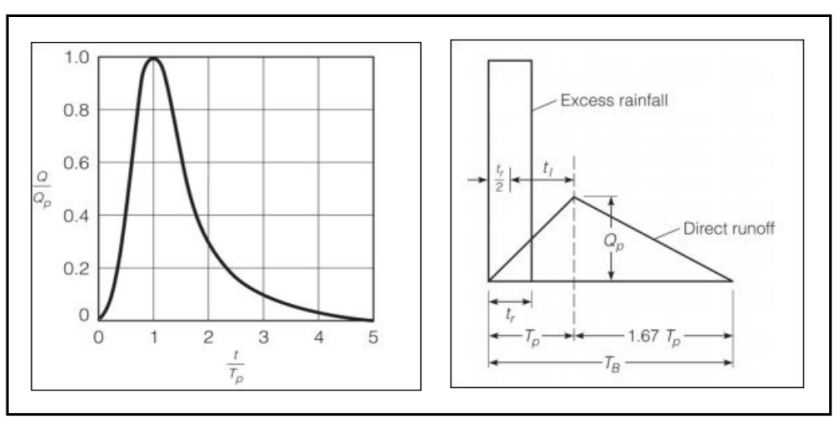

Fig. 1. Soil Service Synthetic unit hydrograph.

\section{Result}

\subsection{Delineation of watershed}

The delineation of the watershed in this study was carried out by using ArcGIS 10.5 software. The input data was DEM data downloaded from USGS EarthExplorer. Due to the running process, it was resulted that the total area of Krueng Kluet Watershed is $2,954.31 \mathrm{~km}^{2}$. It can be viewed in Figure 2.

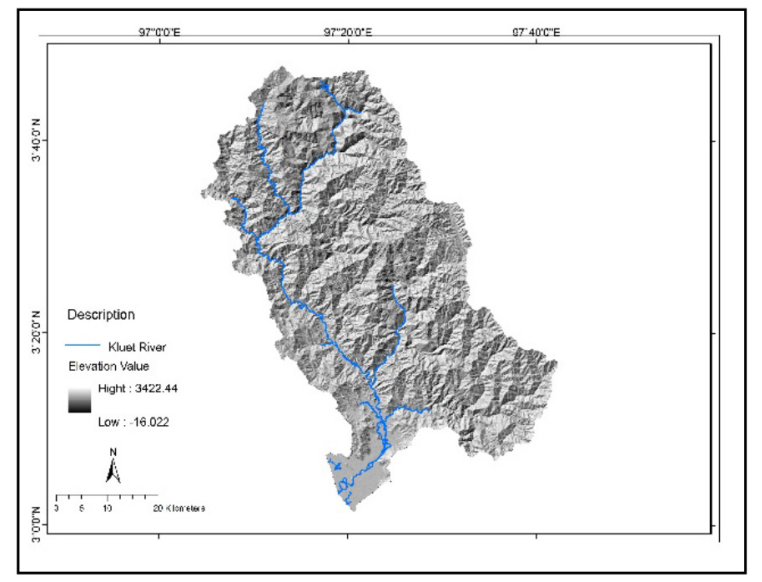

Fig. 2. Krueng Kluet Watershed delineation map.

\subsection{Spatial analysis of land use change}

\subsubsection{Radiometric correction}

Radiometric correction is carried out to improve image quality due to surface reflection errors or the curvature of the earth and other factors including the direction of sunlight, weather conditions, atmospheric conditions and other factors resulting the more accurate 
information. The results of the radiometric correction can be seen in the following figure (Figure 3 and 4).

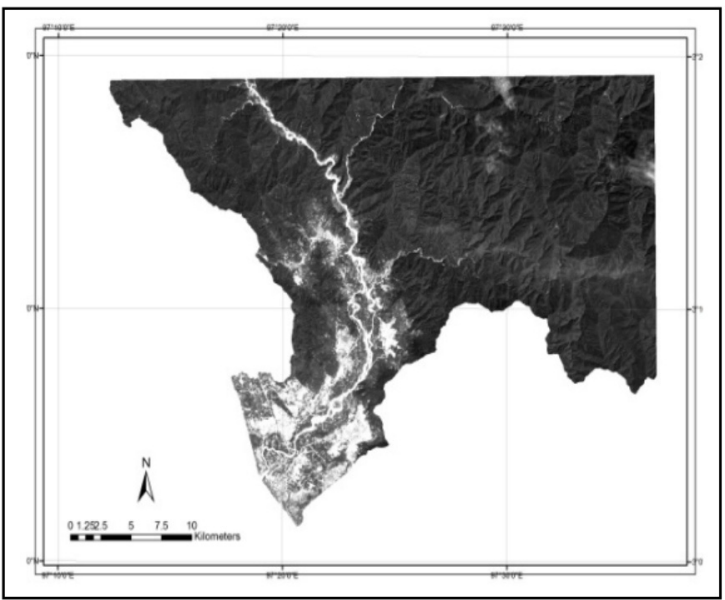

Fig. 3. Before radiometric correction.

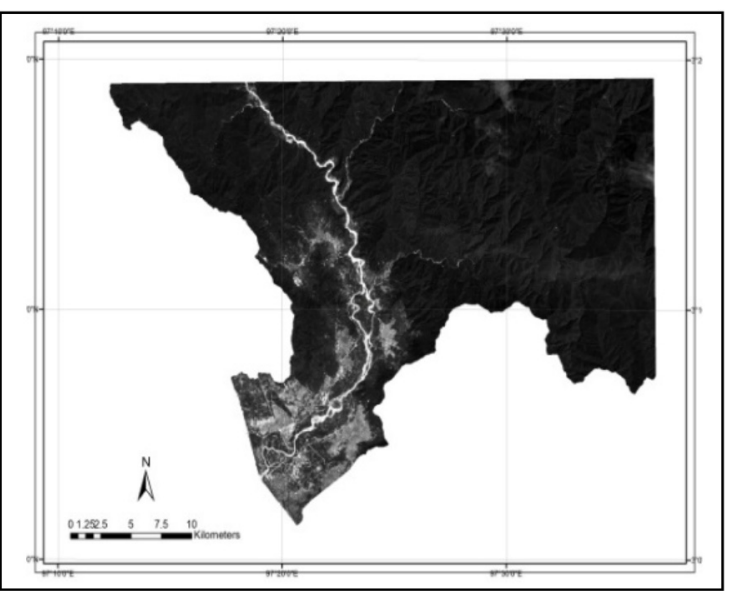

Fig. 4. After radiometric correction.

\subsubsection{Normalized Difference Vegetation Index (NDVI)}

NDVI can be categorized into several groups. NDVI of -1.0 to 1.0 represents wetland, barren rock areas and non-vegetated objects. NDVI of 0.2 to 0.5 represent the rare vegetation, i.e, bush, grassland and old plants. NDVI of 0.6 to 0.9 represents dense vegetation, i.e, temperate and tropical climate forests, the plants on the peak growth phase. The analysis of NDVI can be summarized into the following figures.

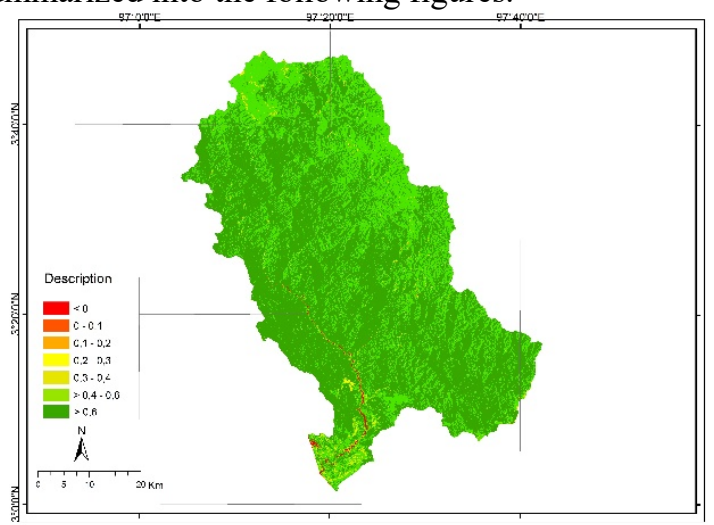

Fig. 5. NDVI of Krueng Kluet Watershed on 1998.

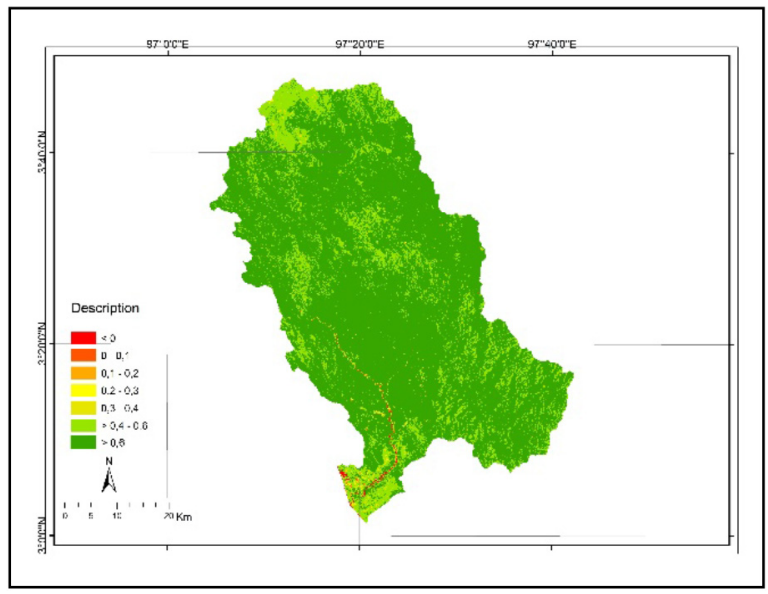

Fig. 6. NDVI of Krueng Kluet Watershed on 2008.

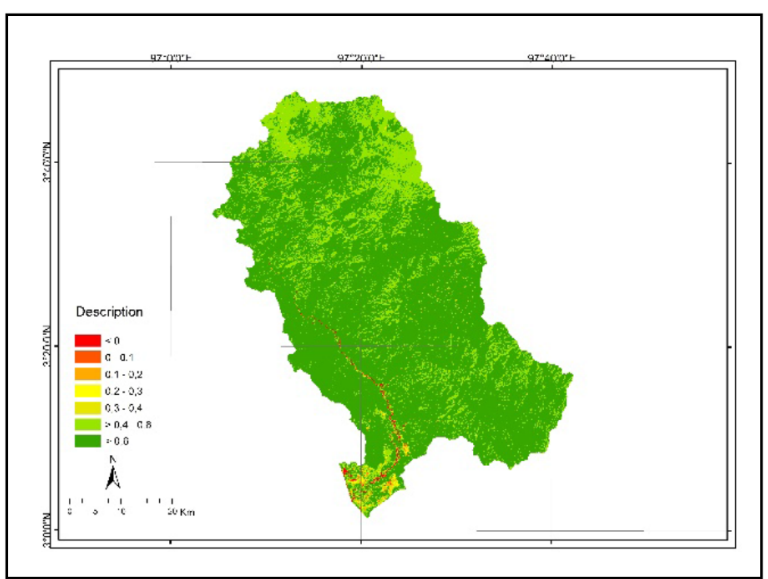

Fig. 7. NDVI of Krueng Kluet Watershed on 2018.

The analysis of land use using NDVI resulted in 7 land use categories as summarized into Table 1. Based on the analysis output, the land use changes during 20 (twenty) years period from 1998 to 2018 can be calculated. Land use change due to classification output during 20 (twenty) years period can be explained in Table 2 and 3 .

Table 2. NDVI classification

\begin{tabular}{|c|c|c|c|c|}
\hline \multirow{2}{*}{ NDVI } & \multirow{2}{*}{$\begin{array}{l}\text { Land Use } \\
\text { Type }\end{array}$} & \multicolumn{3}{|c|}{ Total Area $\left(\mathrm{Km}^{2}\right)$} \\
\hline & & 1998 & 2008 & 2018 \\
\hline$<0$ & Water & 6.36 & 4.51 & 9.47 \\
\hline $0-0.1$ & $\begin{array}{l}\text { Settlement } \\
\text { / urban area }\end{array}$ & 1.68 & 2.60 & 3.86 \\
\hline $0.1-0.2$ & $\begin{array}{c}\text { Bareland } \\
\text { area }\end{array}$ & 2.83 & 3.43 & 7.53 \\
\hline $0.2-0.3$ & Grassland & 8.25 & 6.26 & 12.56 \\
\hline $0.3-0.4$ & Bush & 28.35 & 19.61 & 19.58 \\
\hline $0.4-0.5$ & Plantation & 373.66 & 501.92 & 611.68 \\
\hline$>0.5$ & Forest & $2,533.18$ & $2,415.98$ & 2289.56 \\
\hline \multicolumn{2}{|c|}{ Total } & $2,954.31$ & $2,954.31$ & $2,954.31$ \\
\hline
\end{tabular}


Table 3. Land use change due to classification output

\begin{tabular}{|c|c|c|c|c|}
\hline \multirow{2}{*}{ NDVI } & \multirow{2}{*}{$\begin{array}{c}\text { Land Use } \\
\text { Type }\end{array}$} & \multicolumn{3}{|c|}{ Total Area (\%) } \\
\cline { 3 - 5 } & & 1998 & 2008 & 2018 \\
\hline 00 & Water & 0,22 & 0,15 & 0,32 \\
\hline $0-0.1$ & $\begin{array}{c}\text { Settlement } \\
\text { /urban area }\end{array}$ & 0,06 & 0,09 & 0.13 \\
\hline $0.1-0.2$ & $\begin{array}{c}\text { Bareland } \\
\text { area }\end{array}$ & 0,10 & 0,12 & 0,25 \\
\hline $0.2-0.3$ & $\begin{array}{c}\text { Grassland } \\
0.3-0.4\end{array}$ & 0,28 & 0,21 & 0,42 \\
\hline $0.4-0.5$ & Bush & 0,96 & 0,66 & 0,66 \\
\hline$>0.5$ & Forest & 85,75 & 81,78 & 77,50 \\
\hline & Total & 100,00 & 100,00 & 100,00 \\
\hline
\end{tabular}

\subsection{Peak discharge calculation using scs method}

Peak discharge calculation using hydrograph method requires Excess Rainfall Hytograf (ERH) of effective rainfall. ERH calculation by using SCS method requires Curve Number $(\mathrm{CN})$ of each observation describing watershed characteristic both land use and soil type.

\subsubsection{Curve Number (CN) Factor Classification}

The classification of soil is categorized based on FAO Digital Soil Map of the World. CN calculation can be shown in Map.

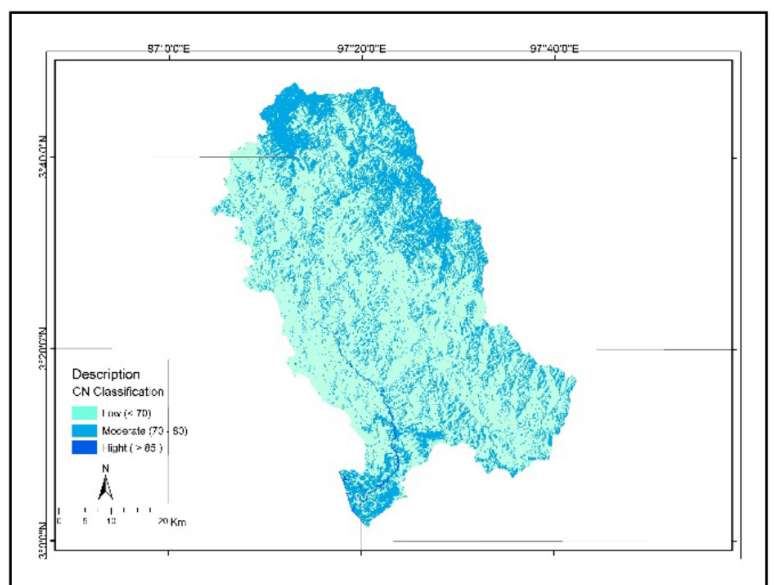

Fig. 8. CN of Krueng Kluet Watershed on 1998.

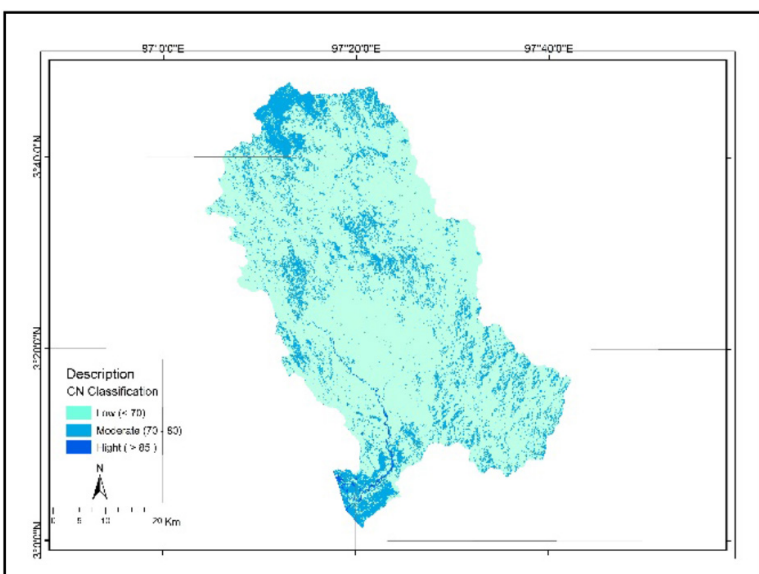

Fig. 9.CN of Krueng Kluet Watershed on 2008.

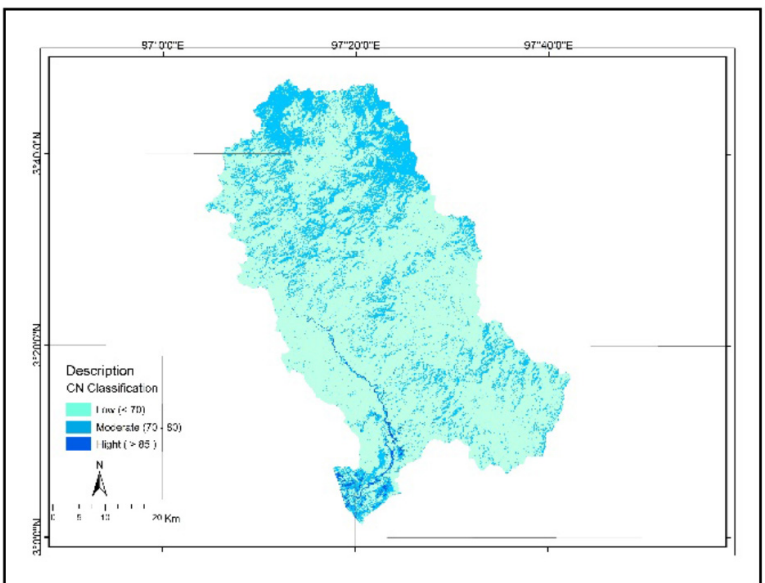

Fig. 10. CN of Krueng Kluet Watershed on 2018.

$\mathrm{CN}$ classification maps describe that $\mathrm{CN}$ of 1998 is 61.8. It increases in 2008 to 62.1. it also improves in 2008 to become 62.5 .

\subsubsection{Potential maximum infiltration (S)}

The Potential maximum infiltration and surface flow related to curve number $(\mathrm{CN})$ as explained in Equation 7. The calculation rainfall and surface flow variation is summarized in the below table.

Table 4. Potential maximum infiltration (S)

\begin{tabular}{|c|c|c|c|c|c|}
\hline \multicolumn{2}{|c|}{1998} & \multicolumn{2}{c|}{2008} & \multicolumn{2}{c|}{2018} \\
\hline $\mathrm{CN}$ & $\begin{array}{c}\mathrm{S} \\
(\mathrm{mm})\end{array}$ & $\mathrm{CN}$ & $\begin{array}{c}\mathrm{S} \\
(\mathrm{mm})\end{array}$ & $\mathrm{CN}$ & $\begin{array}{c}\mathrm{S} \\
(\mathrm{mm})\end{array}$ \\
\hline 61.8 & 157.003 & 62.1 & 155.018 & 62.5 & 152.400 \\
\hline
\end{tabular}

\subsubsection{Excess rainfall (Q)}

The effective rainfall calculation using SCS method requires maximum daily rainfall from 1998 to 2018 is $141.49 \mathrm{~mm}$ in 2016. The total of surface run off volume (Q) is calculated by multiply effective rainfall and Krueng Kluet Watershed Area as 2,954.314 km². The output of effective rainfall calculation can be summarized as below table. 


\begin{tabular}{|c|c|c|c|}
\hline Year & $\begin{array}{c}\text { ble 5. Exc } \\
\begin{array}{c}\text { P } \\
(\mathrm{mm})\end{array}\end{array}$ & $\begin{array}{c}\mathrm{S} \\
(\mathrm{mm})\end{array}$ & $\begin{array}{c}\mathrm{Q} \\
(\mathrm{m})\end{array}$ \\
\hline 1998 & \multirow{3}{*}{141.49} & 157.003 & 0.045 \\
\hline 2008 & & 155.018 & 0.046 \\
\hline 2018 & & 152.400 & 0.047 \\
\hline
\end{tabular}

The flood hydrograph is calculated by multiply effective rainfall and unit hydrograph [10]. The maximum peak discharge in 1998 is $3,774.48 \mathrm{~m}^{3} / \mathrm{sec}$, in 2008 is $4,525.81 \mathrm{~m}^{3} / \mathrm{sec}$, and in 2018 is $4,568.31 \mathrm{~m}^{3} / \mathrm{sec}$. The result of flood hydrograph of 1998, 2008, and 2018 are summarized as Figure 11-13.

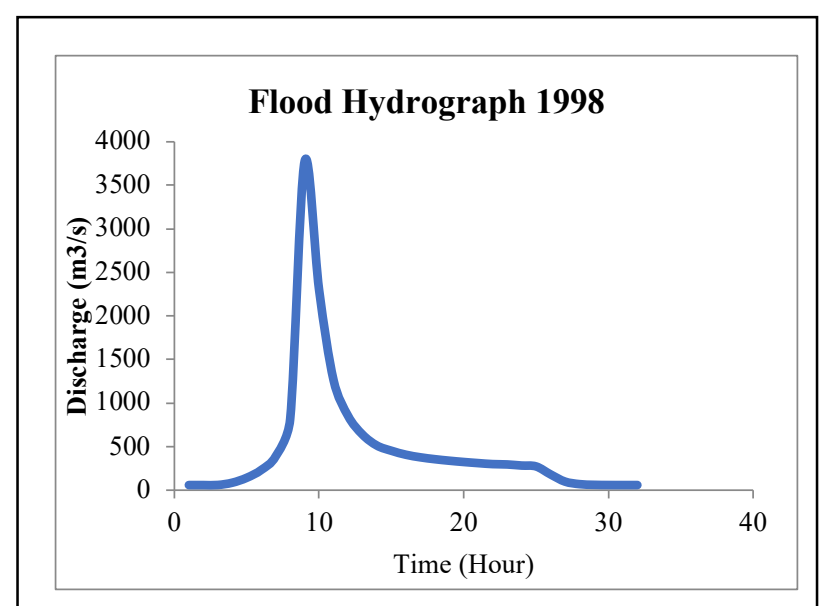

Fig. 11. Flood hydrograph of 1998.

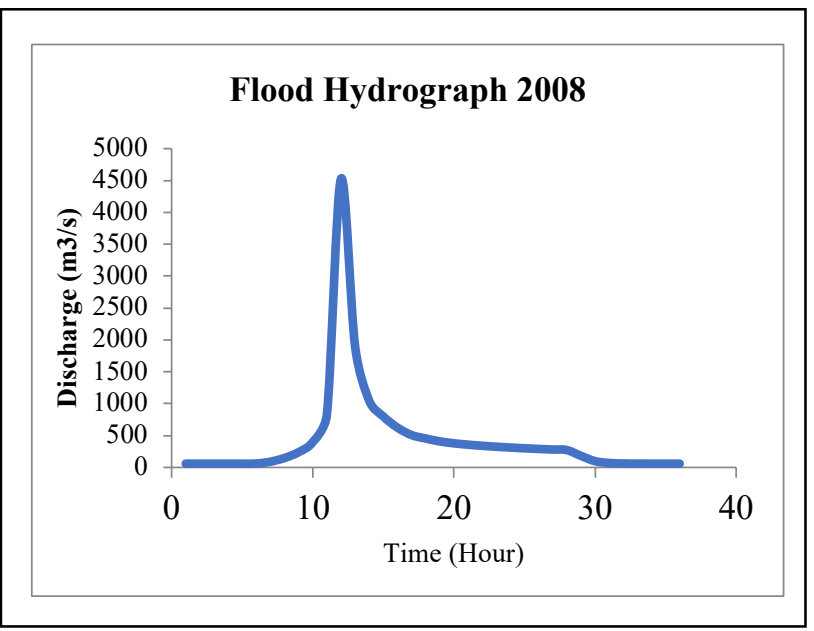

Fig. 12. Flood hydrograph of 2008.

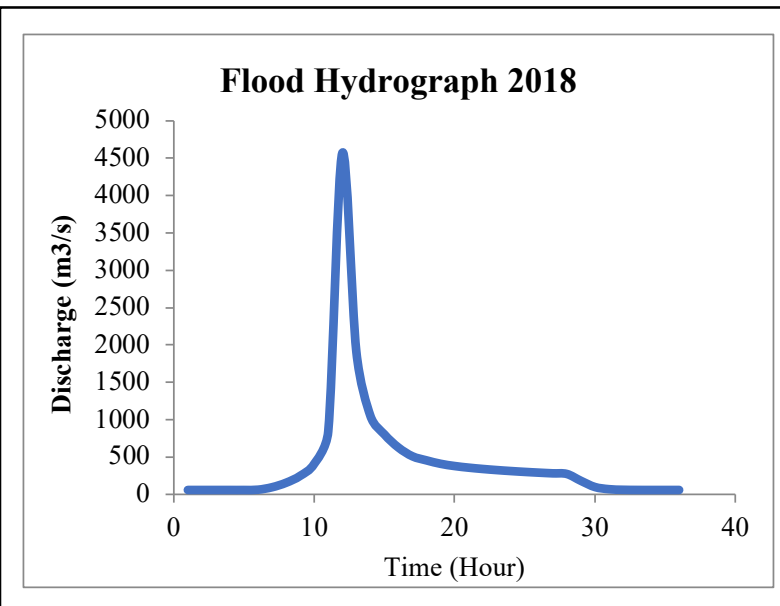

Fig. 13. Flood hydrograph of 2018.

\section{Conclusion}

The results of the study described that there were significant land use changes mostly of the plantation, settlement and forest areas. Over a 20 -years period of observation, we found that there was an increase in the plantation and settlement areas, while in contrary the forest area.

In the period of $1998-2008$, there were the increase of plantation area from $12.5 \%$ to $16.99 \%$, bareland area from $0.10 \%$ to $0.12 \%$ and settlements/urban area and from $0.06 \%$ to $0.09 \%$. Otherwise, the forest area, bush area, grassland area and water area were significantly decreased i.e. from $85.75 \% 81.78 \%$, from $0.96 \%$ to $0.66 \%$, from $0.28 \%$ to $0.21 \%$, and from $0.22 \%$ to $0.15 \%$.

In the period of $2008-2018$, there were the increase of water area, settlements/urban area, bareland area, grassland area, and plantation i.e. from $0.15 \%$ to $0.32 \%$, from $0.09 \%$ to $0.13 \%, 0.12 \%$ to $0.25 \%$, from $0.21 \%$ to $0.42 \%$, and $16.99 \%$ to $20.70 \%$ respectively. Whereas the forest are significantly decreased to $4.28 \%$. Bush area was constant and the area was still $0.66 \%$.

This suggests a significant changes of forest, plantation and settlement. The forest decrease from $85.75 \%$ in 1998 to $77.50 \%$ in 2018 while the plantation and settlement increase from $12.65 \%$ in 1998 to $20.70 \%$ and from $0.06 \%$ in 1998 to $0.13 \%$ in 2018 . The change of forest and plantation and settlement impact significantly to the Curve Number (CN). The land use changes have also increased the Curve Number $(\mathrm{CN})$ of Krueng Kluet Watershed, i.e, 61.8 in 1998,62.1 in 2008, and $62.5 \mathrm{in} 2018$. The maximum peak discharge in 1998 is $3,774.48 \mathrm{~m}^{3} / \mathrm{sec}$, in 2008 is $4,525.81 \mathrm{~m}^{3} / \mathrm{sec}$, and in 2018 is $4,568.31 \mathrm{~m}^{3} / \mathrm{sec}$.

The land use analysis using Normalized Difference Vegetation Index (NDVI) of 1998 to 2018 resulted the changes of forest and plantation areas. The forest area decreases while the plantation areas increases. The more forest area decreases, the more $\mathrm{CN}$ (curve number) increase. It moderately contribute to the increase of flood discharge in every observation year.

The forest reduction impact flood discharge improvement. It influences sediment supply to the river. The sediment will load in the bottom of the river and affecting the decreasing of river's capacity. The 
discharge improvement and the river's capacity impact flood risk improvement.

\section{References}

1. Suripin, Soil and Water Resources Conservation (Andi, Yogyakarta, 2001)

2. A. Watering Institution, The Final Report of The Flood Control and Krueng Kluet River Management in South Aceh District (Aceh Government, Banda Aceh, 2015)

3. Haba Rakyat, Kruet River Erosion become higher, the community move the grave, (https://habarakyatonline.com/erosi-sungaikluet-makin-parah-warga-terpaksa-bongkarkuburan/, accessed 2 January 2019)4. O. Laoh, IPB (2002).

4. O. E. H. Laoh, Physical, Social, Economic, and Land Use Factors Correlations to Erosion and Sedimentation in Catchment Area (Tondano Case Study, North Sulawesi ), (IPB, Bogor, 2002).

5. G. P. Verrina, D. D. Anugrah, and Sarino, 2013 1, 12 (n.d.)

6. P. K. Langat, L. Kumar, and R. Koech, 201992 (n.d.)

7. T. Lilesand and R. W. Kiefer, Remote Sensing and Image Interpretation (Gajah Mada University Press, Yogyakarta, 1997)

8. B. Nath, $20142,(21-27)$

9. D. F. Morawitz, T. Blewett M., A. Cohen, and M. Albert, 200685 (n.d.)

10. M. M. Aburas, S. H. Abdullah, M. F. Ramli, and Z. Ash'aari, 2015238 (n.d.)

11. R. H. McCuen, Hydrologic Analysis and Design (Pretice-Hall, Inc, Upper Saddle, New Jersey, US, 1989)

12. C. Asdak, Hydrology and Watershed Management (Gadjah Mada University Press, Yogyakarta, 2002)

13. V. T. Chow, D. R. Maidment, and L. W, Applied Hydrology (Mc Grow-Hill Science Engineering, 1998) 